\title{
Determinants of Export Demand Function for Malawi Tobacco
}

\author{
Nomore Nkhoma1,2, Yohana James Mgale ${ }^{1,3}$, Yunxian Yan ${ }^{1 *}$ \\ ${ }^{1}$ College of Economics and Management, Jilin Agricultural University, Changchun, China \\ ${ }^{2}$ Department of Nutrition, HIV \& AIDS, Ministry of Health, Lilongwe, Malawi \\ ${ }^{3}$ Department of Rural Development and Regional Planning, Institute of Rural Development Planning, Dodoma, Tanzania \\ Email: nomorenk@gmail.com, mgaleyj@gmail.com, ‘yanyunxian@126.com
}

How to cite this paper: Nkhoma, N., Mgale, Y. J., \& Yan, Y. X. (2021). Determinants of Export Demand Function for Malawi Tobacco. Open Journal of Business and Management, 9, 1836-1848.

https://doi.org/10.4236/ojbm.2021.94099

Received: May 4, 2021

Accepted: July 17, 2021

Published: July 20, 2021

Copyright (c) 2021 by author(s) and Scientific Research Publishing Inc. This work is licensed under the Creative Commons Attribution International License (CC BY 4.0).

http://creativecommons.org/licenses/by/4.0/

\section{(c) (i) Open Access}

\begin{abstract}
This paper examines the export demand function of Malawi tobacco using panel data from 1997 to 2019. It estimates the relationship of tobacco quantity exported with Malawi's export price, competitor's export price, Gross Domestic Product (GDP), Real effective exchange rate (REER) as well as the impact of the World Health Organization's (WHO) Framework Convention on Tobacco Control (FCTC). A double log fixed effects model with driscollkraay standard errors as well as fixed effects model with Least Square Dummy Variables (LSDV) model was used for empirical estimation. The empirical results confirmed that there exists a significant relationship among Malawi tobacco export demand, trade partner's real income and export price. Furthermore, REER was elastic, while own price and cross price elasticities were less than zero. The results indicated that Malawi should take advantage of the high incomes of the tobacco importing countries to enhance international market share.
\end{abstract}

\section{Keywords}

Export Demand, Tobacco, Panel Data, Fixed Effects, Malawi

\section{Introduction}

Malawi's economy is predominantly driven by the agricultural sector which accounts for one third of the GDP and nearly 80 percent of the country's employment for decades. Agriculture is considered the engine of Malawi's economic growth, contributing more than 80 percent of the country's total exports (FAO, 2015). The primary agricultural commodities for export, include tobacco, sugar, tea, nuts and pulses. The tobacco sector plays an important role in the agricul- 
ture-based economy of Malawi. Tobacco is the main cash crop accounting for about 10 percent of GDP and more than 60 percent of total exports (FAO, 2015).

Exports play a vital role in determining the national income of a country (Sultanuzzaman et al., 2019). Ideally, an increase in a country's exports will result in a significant increase of its national income. In many developing countries like Malawi, the role of exports is significant for the country's economic growth by generating foreign exchange necessary to finance their imports, which are crucial for capital formation (Senhadji \& Montenegro, 1999). In 2019, the world total export value for Malawi's unmanufactured tobacco was USD 528, 512 and the country exported 136,441 metric tonnes of raw tobacco (ITC, 2020). The top 10 importing countries were Belgium, Germany, Russia Federation, Netherlands, United States of America, Poland, republic of Korea, Turkey, China and Armenia.

The tobacco industry in Malawi faces several challenges which affect export trade and profitability. Even though tobacco prices are rising globally, Malawi tobacco production has suffered from low prices offered by tobacco leaf buying companies who act as a cartel in the country by determining prices at the auction floors. This situation has adversely affected the profitability of tobacco for Malawi. Another challenge is the competition for tobacco export markets, between Malawi and other southern African tobacco producing countries. Countries such as Mozambique, Tanzania, Zambia and Zimbabwe produce the same tobacco leaf as Malawi and share the same export markets. In addition, the WHO adopted the FCTC in 2003, an international treaty to reduce demand for tobacco products and address supply issues. This anti lobby campaign imposes tighter regulations and heavy taxes on tobacco leaf, a major source of export earnings for the country. Although Malawi has not officially ratified to this treaty, in 2004 it became a party to the FCTC through what is known as accession, which has equivalent effect to ratification (FCTC, 2014). Since tobacco is the major source of foreign exchange in Malawi, shortfalls in the national tobacco crop and low prices for tobacco in world markets have negative effect on the national economy. It is against this background that this study would like to analyse the determinants of tobacco exports for Malawi to selected world markets. There are no documented records for studies which analyzed Malawi tobacco export demand estimates to major importing countries. The findings from this study will provide empirical information on the export demand function for Malawi Tobacco. The information can be used by government and policy makers to enrich already existing international trade policies and data. Furthermore, knowledge of export demand elasticities is essential for providing an insight on how to deal with the impacts of Balance of trade and institute measure which can effectively boost the economy of the country.

\section{Review of the Literature}

Exporters and importers behaviour is addressed mainly in international trade li- 
terature. Export and import demand estimation methods have been commonly used to investigate different agricultural commodities. Numerous studies have attempted to estimate trade functions both locally and internationally. However, in Malawi literature on export demand function is still very scarce when compared to other countries, especially developed countries. While some of the studies are country-specific (Munemo et al., 2007; Khan, 1974), others are crosssectional (Gregori \& Giansoldati, 2020), and panel data based studies (Maziya et al., 2016). However, these studies differ in terms of the models used, some are based on disaggregated models (product specific) while others are focused on aggregate models.

Bokosi (2015) applied the Vector Autoregressive Regression (VAR) technique to annual data from 1980 to 2013 to provide empirical evidence on the long-run relationship between export trade and economic growth in Malawi. The export trade was disaggregated into services and goods exports, therefore the paper estimated two models. The first model dealt with the relationship between export of services and growth, and the other one determined the relationship between goods export and growth. The results found no evidence for long-run relationship between export of services and goods on economic growth, but the empirical results suggested existence of a short-run nexus between export of goods and economic growth. The Granger causality test results also confirmed an existence of a unidirectional causality from goods exports to economic growth and another unidirectional causality from goods exports to service exports. Senhadji \& Montenegro (1999) estimated export demand elasticities for a large number of developing and industrial countries, using time-series techniques that accounted for the nonstationarity in the data. The study found that exports do react to both the trade partners' income and to relative prices. It further revealed that Africa faced the lowest income elasticities for its exports, while Asia had both the highest income and price elasticities.

A similar study conducted by Olofin \& Babatunde (2009) analyzed panel data from 20 Sub-Saharan African (SSA) countries including Malawi. Econometric evidence revealed that relative prices and trading partners' income were important factors that explained SSA export performance. Exports in SSA were price and income inelastic. In addition, the estimated short-run price as well as the long run price and income elasticity varied across regions and commodities in SSA. The poor performance of SSA exports was attributed to low elasticities for demand for African exports in relation to changes in world income. Saghaian (2017) estimated the export demand function for US corn and soybeans exported to China, Japan \& EU for the period 1980-2011. The study employed a log-linear model of panel data analysis. The logarithm estimates showed that China had more elastic demand of 2.5 , while income elasticity of Japan was close to 1 . The parameter estimates for price of soybean as a cross price was significant for China and EU and parameter estimates for price of corn as a cross price was only significant for Japan. The positive sign obtained revealed soybeans and corn 
could be substitutes in those countries.

Another study conducted by Soltani and Saghaian (2012) estimated the export demand function for US raisins from 1992-2008. The study investigated the export demand for Australia, Canada, Germany, Japan and United Kingdom using panel data analysis approach to determine own-price, cross-price, and income elasticities for the US raisins. The results were not significant for Iran and Turkey price. For Canada only price for Iran was not significant. All variables for Germany and UK were significant except for exchange rate. Similarly, Zheng et al. (2012) identified the major factors affecting export demand for US pistachios. The impacts of market conditions and the effects of food safety shocks were investigated. The study used a panel data analysis approach. The results from their study indicated that US pistachio producers should take advantage of their advanced technology and reputation for higher food safety standards to enhance international market share.

Zafar (2012) estimated Saudi Arabia's export demand function using bound test approach to cointegration which was developed by (Pesaran et al., 2001). The results showed that there is a long run equilibrium relationship between demand for export, world income and real effective exchange rate. The demand for Saudi's export with respect to world income and real effective exchange rate were found to be elastic both in the short run and long run. The exports were found to be more elastic in the short run than in the long run with respect to both variables.

Ibrahim (2012) investigated empirically the critical parameters of merchandise export demand function for Egypt by using annual time series-cross section data from 1990-2008 and by applying fixed effect model. The empirical results revealed a significant relationship among the real value of merchandise exports for Egypt and trade panther's income, relative exports price, trade panther's real exchange rates. All variables showed positive relationships as expected and negative relationship for real price as pre assumed. The elasticities of real income, relative price and real exchange rates were found to be smaller than unity. Bobić (2009) estimated income and price elasticities of imports and exports, as well as to quantify the effect of other potential trade determinants in Croatia. The estimated model was based on the imperfect substitute's model developed by (Goldstein and Khan, 1985). Dynamic panel data methods were applied to disaggregate data and. The Arellano-Bond method was used to estimate the model in first differences. The estimated income and price elasticity coefficients, both in the import and in the export model, had the expected signs-increase in income positively affected exports and imports, while increase in prices lower them.

A review of literature has proved that a lot of research on determinants of export demand analysis has been conducted, but most of them only focused on aggregate products and services for Malawi. Therefore, this study intends to focus on export demand for a specific commodity with reference to raw tobacco exports for Malawi using panel data from 1997 to 2019. 


\section{Data and Methods}

\subsection{Data}

This study utilizes secondary data on agriculture and trade. 12 major importing countries are selected for this study. These are Belgium, Egypt, Germany, China, Russia, Poland, United States, South Korea, Japan, Netherlands, Ukraine and Turkey. Table 1 below shows the import data for these countries over the years. Annual data for the variables were chosen for a period of 23 years from 1997 to 2019 for the estimation. This year span incorporates the period before and after

Table 1. Malawi tobacco exports.

\begin{tabular}{|c|c|c|c|c|c|c|c|c|c|c|c|c|}
\hline & \multicolumn{12}{|c|}{ Raw tobacco leaf imports from Malawi (Million $\mathrm{Kg}$ ) } \\
\hline & Belgium & China & Egypt & Germany & Japan & Netherlands & Poland & $\begin{array}{c}\text { Rep. } \\
\text { of Korea }\end{array}$ & Russia & Turkey & Ukraine & $\begin{array}{l}\text { United } \\
\text { States }\end{array}$ \\
\hline 1997 & 0 & 0.00 & 2.30 & 14.12 & 10.83 & 13.77 & 2.47 & 0.00 & 0.01 & 0.92 & 0.08 & 19.82 \\
\hline 1998 & 0 & 0.00 & 4.48 & 18.42 & 7.99 & 14.47 & 2.41 & 0.00 & 0.21 & 4.84 & 2.26 & 22.36 \\
\hline 1999 & 2.63 & 0.00 & 11.63 & 18.42 & 9.97 & 6.11 & 0.22 & 0.00 & 0.09 & 5.32 & 0.36 & 15.61 \\
\hline 2000 & 1.25 & 0.14 & 5.62 & 19.32 & 9.22 & 4.79 & 0.06 & 0.00 & 0.41 & 1.57 & 1.36 & 16.55 \\
\hline 2001 & 1.59 & 0.60 & 24.93 & 24.75 & 6.76 & 4.42 & 0.08 & 0.00 & 0.57 & 0.49 & 1.26 & 17.25 \\
\hline 2002 & 2.48 & 0.02 & 9.96 & 16.01 & 4.66 & 4.24 & 0.27 & 0.00 & 4.66 & 0.60 & 0.74 & 18.98 \\
\hline 2003 & 3.71 & 0.00 & 10.65 & 15.84 & 10.13 & 7.58 & 0.82 & 0.49 & 3.76 & 2.29 & 1.00 & 16.39 \\
\hline 2004 & 3.34 & 0.00 & 9.73 & 12.70 & 3.76 & 8.12 & 1.72 & 0.49 & 2.86 & 1.81 & 0.54 & 9.45 \\
\hline 2005 & 2.23 & 1.93 & 9.13 & 15.20 & 3.45 & 8.75 & 4.62 & 0.45 & 10.18 & 1.35 & 0.63 & 16.00 \\
\hline 2006 & 11.11 & 0.40 & 13.82 & 28.34 & 0.01 & 9.12 & 6.69 & 2.09 & 10.89 & 3.44 & 1.31 & 23.05 \\
\hline 2007 & 19.21 & 1.16 & 8.84 & 14.52 & 0.02 & 7.14 & 4.95 & 5.38 & 11.69 & 2.85 & 1.15 & 6.36 \\
\hline 2008 & 24.99 & 3.54 & 5.90 & 7.98 & 0.00 & 10.55 & 6.20 & 4.83 & 6.95 & 3.72 & 2.76 & 6.73 \\
\hline 2009 & 46.67 & 3.45 & 15.62 & 14.96 & 0.01 & 11.07 & 4.47 & 2.00 & 11.95 & 4.31 & 2.08 & 9.81 \\
\hline 2010 & 30.19 & 4.65 & 25.33 & 13.89 & 0.00 & 10.21 & 4.44 & 2.93 & 4.77 & 1.17 & 1.34 & 9.86 \\
\hline 2011 & 22.75 & 5.59 & 13.60 & 12.32 & 0.00 & 5.70 & 6.09 & 5.70 & 10.64 & 3.02 & 3.16 & 11.93 \\
\hline 2012 & 22.34 & 4.90 & 16.96 & 10.78 & 0.00 & 8.92 & 6.83 & 6.84 & 14.64 & 1.38 & 4.91 & 13.99 \\
\hline 2013 & 17.96 & 7.54 & 2.81 & 9.94 & 0.00 & 8.29 & 5.94 & 5.98 & 15.18 & 2.51 & 3.33 & 11.32 \\
\hline 2014 & 34.61 & 7.68 & 16.52 & 11.08 & 0.00 & 3.78 & 109.84 & 3.12 & 13.43 & 2.41 & 2.33 & 9.61 \\
\hline 2015 & 27.53 & 6.72 & 15.69 & 10.42 & 0.00 & 4.96 & 6.36 & 2.88 & 10.52 & 0.83 & 5.14 & 6.58 \\
\hline 2016 & 44.47 & 7.03 & 7.62 & 11.50 & 0.00 & 7.31 & 7.71 & 6.25 & 11.46 & 0.73 & 3.09 & 12.04 \\
\hline 2017 & 49.14 & 4.78 & 14.86 & 12.85 & 0.00 & 5.17 & 8.33 & 2.05 & 8.79 & 0.48 & 4.81 & 4.88 \\
\hline 2018 & 32.34 & 3.95 & 13.93 & 10.62 & 0.00 & 10.67 & 10.01 & 2.74 & 8.70 & 0.17 & 7.51 & 9.37 \\
\hline 2019 & 42.30 & 3.91 & 13.70 & 5.84 & 0.00 & 9.65 & 3.46 & 4.71 & 10.01 & 0.84 & 3.56 & 6.82 \\
\hline
\end{tabular}


the WHO treaty on tobacco exports. Data for Malawi raw tobacco export ${ }^{1}$ quantities and export values to destination markets were collected from UNCOMTRADE using the HS4 digit code (2401). Data for GDP and real exchange rate were sourced from the International Monetary Fund (IMF) international financial statistics and the World Bank Database. GDP data are in current U.S. dollars. Dollar figures for GDP are converted from domestic currencies using single year official exchange rates. Real effective exchange rate is the nominal effective exchange rate (a measure of the value of a currency against a weighted average of several foreign currencies) divided by a price deflator or index of costs, 2010 was used as the base year. For this study, export prices are the average values which were calculated by dividing the total export values by the total export quantities of raw tobacco for both Malawi and for the competing countries which are Zimbabwe ${ }^{2}$, Tanzania, Zambia and South Africa. Dummy variables for WHO treaty impact were created in STATA by assigning the value 0 for the period 1997 to 2005, and the value 1 for the years 2006 to 2019. Malawi became a party of the FCTC through what is known as accession after the year 2004 (FCTC, 2014). Therefore, the demarcation of the years incorporates and assess the impact of the treaty on Malawi tobacco export demand in these two periods.

\subsection{Model Specification}

The main objective of this study is to estimate the determinants of the export demand function for Malawi tobacco. Export demand specification is necessary for meaningful export forecast, international trade planning and policy formulation (Arize \& Malindretos, 2014). This study adopts a variant of the imperfect substitutes model developed by (Goldstein and Khan, 1985). The imperfect substitutes model was chosen because it explains the theoretical foundation of the empirical analysis of trade flows across countries. The basic assumption of the imperfect substitutes model is that neither imports nor exports are perfect substitutes for domestic goods. Theoretically, there are three main variables used in export demand functions (Guci, 2008). These include product price which is the main explanatory variable; foreign income, which represents the purchasing power of the trading partner; and lastly, the exchange rates which is a relative price that is crucial in affecting imports.

Export demand function will be expressed as a double-log model where the coefficients will show the own and cross price elasticities. Mathematically the export demand equation is specified as:

$$
\begin{aligned}
\ln Q_{i, t}= & \beta_{0}+\beta_{1} \ln X P_{i, t}+\beta_{2} \ln G D P_{i, t}+\beta_{3} \ln C X P_{i, t} \\
& +\beta_{4} \ln R E E R_{i, t}+\beta_{5} D_{i, t}+\varepsilon_{i}
\end{aligned}
$$

While the real effective exchange rate is calculated as

${ }^{1}$ Tobacco export quantities and export values included in this study are for unmanufactured or raw tobacco.

${ }^{2}$ Zimbabwe is Malawi's major competitor in tobacco production in the African region. 


$$
R E E R=\frac{P_{d}}{e * P_{f}}
$$

whereby, $P_{d}$ is Domestic price in the importing countries; $P_{f}$ is U.S. price in foreign countries; e is the nominal exchange rate, $Q_{i, t}$ is Malawi export quantities of tobacco to country $i$ in time $t, X P_{i, t}$ is Malawi tobacco export prices to country $i$ in time $t, G D P_{i, t}$ is GDP of importing country $i$ in time $t, C X P_{i, t}$ is Competitors $i$ tobacco export price in time $t$ (Zimbabwe, Tanzania, Zambia and South Africa); $R E E R_{i, t}$ is the real effective exchange rates between country $i$ 's currency and the U.S. dollar in time $t, D_{i, t}$ is dummy variable country $i$ in time $t ; D=0$ before WHO treaty and $D=1$ after WHO treaty; $\varepsilon_{i}=$ Error term.

The subscript $i$ represents the countries, and the subscript $t$ represents time, from 1997 to 2019. All variables are both time variant and cross sectional variant. The logarithmic function makes values with different scales become more comparable. The coefficients are in elasticity form, so they will be much easier to interpret.

Fixed effects were also used with Least Square Dummy Variable model (LSDV) by adding dummy variables for each entity (country). The LSDV provides a good way of understanding fixed effects. The effect of each explanatory variable is mediated by the differences across countries. By adding the dummy for each country we are estimating the pure effect of the independent variable (by controlling for the unobserved heterogeneity). Each dummy is absorbing the effects particular to each country.

The fixed effects model with dummy variables is as follows:

$$
\gamma_{i t}=\beta_{0}+\beta_{1} X_{1, i t}+\cdots+\beta_{k} X_{k, i t}+\gamma_{2} E_{2}+\cdots+\gamma_{n} E_{n}+u_{i t}
$$

In Equation (3), $Y_{i t}$ is the dependent variable which is Malawi tobacco export quantities; $X_{k, i t}$ represents a set of independent variables which are XP, CXP, GDP and REER; $\beta_{k}$ is the coefficient for the independent variable; $u_{i t}$ is the error term; $E_{n}$ is the entity $n$ (country). Since they are binary (dummies) we have $n-1$ entities included in the model; $\gamma_{2}$ is the coefficient for the binary regressors (entities).

\section{Results and Discussion}

\subsection{Diagnostic Tests}

Since the macro panel data used for the analysis is over 20 years, it is prone to suffer from serial correlation, which may cause standard errors or coefficients to be smaller than they normally are and higher R-squared. A Lagram-Multiplier test for serial correlation was used to test for the presence of first order auto-correlation. The $p$-value of 0.1360 show that the data did not suffer from serial correlation.

The data was also checked for the presence of heteroscedasticity for the fixed effects model using the modified Wald test for groupwise heteroscedasticity. The null hypothesis is homoscedasticity (constant variance). The $p$-value was less 
than 0.05 therefore the model suffered from heteroscedasticity.

The Pesaran CD (cross-sectional dependence) test is used to test whether residuals are correlated across entities. Cross sectional dependence may result in biasness of model results. The Pesaran (2012) test indicated presence of crosssectional dependence. According to Hoechle, to treat for cross-sectional dependence, we used Driscoll and Kraay standard errors. Driscoll Kraay standard errors are robust and also treats for heteroscedasticity (Hoechle, 2007).

\subsection{Empirical Results}

Panel estimation can be done using pool estimation of fixed effect and random effect. For this study both the fixed effects model and the random effects model estimates were appropriate. A Hausman test was used to determine the best fitting model with unbiased, consistent, and efficient estimators. The test determines whether there is a significant difference between the fixed and random effects estimators by testing the null hypothesis that the difference between the fixed and random effects is zero. The results showed a chi-square (5) of 21.60 with a $p$-value of 0.003 which was significant at one percent level. Therefore, the null hypothesis was rejected and the fixed effects model was chosen for the analysis.

\subsubsection{Fixed Effects Model with Driscoll Kraay Standard Errors}

The results from the estimated model with driscoll-kraay standard errors in Table 2 below show that only two out of the seven explanatory variables were statistically significant. GDP which was a proxy for importers income had a $p$-value of 0.057 and was significant at ten percent level. The coefficient of 0.428 means

Table 2. Fixed effects with Driscoll-Kraay standard errors.

\begin{tabular}{|c|c|c|c|c|c|c|}
\hline \multicolumn{7}{|c|}{ DRISCOLL-KRAAY STD ERRORS } \\
\hline \multirow{2}{*}{\multicolumn{4}{|c|}{$\begin{array}{l}\text { Regression with Driscoll-Kraay standard errors } \\
\text { Method: Fixed-effects regression }\end{array}$}} & \multicolumn{3}{|c|}{ Number of obs $=93$} \\
\hline & & & & \multicolumn{3}{|c|}{ Number of groups $=11$} \\
\hline \multicolumn{4}{|c|}{ Group variable (i): c_id } & \multicolumn{3}{|c|}{$F(7,18)=17.22$} \\
\hline \multicolumn{4}{|c|}{ maximum lag: 2} & \multicolumn{3}{|c|}{ Prob $>F=0.0000$} \\
\hline \multicolumn{7}{|c|}{ within R-squared $=0.6083$} \\
\hline \multicolumn{7}{|c|}{ Drisc/Kraay } \\
\hline lnMw_Qty & Coef. & Std. Err. & $t$ & $p>\mathrm{t}$ & [95\% Conf.] & [Interval] \\
\hline lnMw_XP & 0.072 & 0.017 & 4.220 & 0.001 & 0.036 & 0.107 \\
\hline lnZwe_XP & 0.001 & 0.005 & 0.160 & 0.876 & -0.011 & 0.012 \\
\hline lnTza_XP & -0.019 & 0.021 & -0.900 & 0.381 & -0.063 & 0.025 \\
\hline lnSa_XP & -0.007 & 0.011 & -0.620 & 0.544 & -0.029 & 0.016 \\
\hline $\operatorname{lnGDP}$ & 0.428 & 0.210 & 2.030 & 0.057 & -0.014 & 0.870 \\
\hline $\operatorname{lnREER}$ & -0.531 & 0.318 & -1.670 & 0.112 & -1.198 & 0.137 \\
\hline $\mathrm{dt}$ & 0.152 & 0.125 & 1.220 & 0.239 & -0.110 & 0.414 \\
\hline _cons & -9.450 & 4.599 & -2.050 & 0.055 & -19.112 & 0.212 \\
\hline
\end{tabular}


that, a unit increase (One million US) in GDP, increased Malawi tobacco exports by 0.4 kilograms. The results concur with the economic assumptions which states that an increase in income leads to an increase in purchasing power. Since the model is in double log function, the coefficients are also elasticities. Malawi tobacco export function is income inelastic.

Export price for Malawi was positively significant at 1 percent level with a $p$-value of 0.001 , therefore it had a positive effect on amount of Malawi tobacco demanded on the international markets. When tobacco export prices in Malawi increase by one dollar, demand for Malawi tobacco increases by 0.07 kilograms. This is contrary to the expected assumption which says that demand rises when export prices fall. This may also be attributed to the fact that tobacco prices are much controlled by tobacco buyers instead of government. Both own price and cross price coefficients are less than one, showing that Malawi tobacco export demand function was price inelastic. This concurred with a study which was conducted by Vidal, which found that tobacco prices do not influence demand, but the amount of sale and the leaf quality (Vidal, 2005). The WHO treaty was not significant. Despite the trade restrictions, tobacco still remains the main source of economic growth and livelihood in Malawi (Jaffee, 2003). In so doing, farmers still continue producing tobacco. Lastly, the real effective exchange rate for importing countries was elastic, which means Malawi tobacco export demand responded to changes in exchange rate.

\subsubsection{Fixed Effects Model with Least Square Dummy Variables (LSDV)}

Table 3 shows the results from the fixed effects model with LSDV. The Overall tobacco export quantities and export prices had a positive and significant relationship. When export price increased by one dollar, export quantities increased by 0.09 kilograms on average from 1997 to 2017. For individual countries, Belgium has a negative relationship with export price and was significant at 10 percent level. China, Egypt, Germany and Netherlands had an inverse relationship to export price and were significant at 5 percent. Poland, Russia, Ukraine and USA were significant at 1 percent. This indicate that when export prices of tobacco decrease in Malawi, demand for Malawi tobacco exports to these countries increase. Only Japan Turkey and South Korea did not benefit from the decrease in tobacco export prices.

Competitor export prices and Malawi tobacco export quantities as a group, had a significantly negative relationship. A decrease in competitor export price by 1 dollar resulted in an increase in tobacco export quantities by 0.02 kilograms. Competitor export price exhibited a positively significant relationship for Malawi tobacco exports to China at 10 percent level. An increase of competitor export price by 1 dollar, increased tobacco exports to China by 0.8 kilograms.

The fixed effect model showed an overall positive and significant relationship between Malawi tobacco exports and importers GDP. In overall, when importers GDP increased by 1 million dollars, Malawi tobacco exports increased by 0.532 
N. Nkhoma et al.

Table 3. Fixed Effects with entities (country dummies) LSDV.

\begin{tabular}{|c|c|c|c|c|c|}
\hline & (XP) & (CXP) & (GDP) & (REER) & $\left(D_{t}\right)$ \\
\hline \multicolumn{6}{|l|}{ VARIABLES } \\
\hline \multirow{2}{*}{ lnMw_XP } & $0.0929^{\star * *}$ & & & & \\
\hline & $(0.0173)$ & & & & \\
\hline \multirow{2}{*}{ Belgium } & $-0.281^{\star}$ & 0.272 & $-1.944^{* * *}$ & 0.0327 & 0.183 \\
\hline & $(0.161)$ & $(0.427)$ & $(0.220)$ & $(0.156)$ & $(0.129)$ \\
\hline \multirow{2}{*}{ China } & $0.323^{* *}$ & $0.845^{\star}$ & $-2.826^{* * *}$ & $0.490^{\star * *}$ & $0.605^{\star * *}$ \\
\hline & $(0.158)$ & $(0.428)$ & $(0.329)$ & $(0.162)$ & $(0.133)$ \\
\hline \multirow{2}{*}{ Egypt } & $-0.403^{* *}$ & 0.0453 & $-1.583^{\star * \star}$ & -0.0816 & 0.0614 \\
\hline & $(0.156)$ & $(0.432)$ & $(0.183)$ & $(0.154)$ & $(0.127)$ \\
\hline \multirow{2}{*}{ Germany } & $-0.381^{* *}$ & 0.173 & $-3.096^{\star * \star}$ & -0.0768 & 0.115 \\
\hline & $(0.158)$ & $(0.426)$ & $(0.301)$ & $(0.153)$ & $(0.127)$ \\
\hline \multirow{2}{*}{ Japan } & 0.253 & 0.284 & $-3.062^{\star \star *}$ & 0.206 & $0.495^{\star \star *}$ \\
\hline & $(0.158)$ & $(0.436)$ & $(0.326)$ & $(0.166)$ & $(0.138)$ \\
\hline \multirow{2}{*}{ Netherlands } & $-0.351^{\star \star}$ & 0.135 & $-2.342^{\star * \star}$ & -0.0958 & 0.0877 \\
\hline & $(0.154)$ & $(0.428)$ & $(0.239)$ & $(0.153)$ & $(0.127)$ \\
\hline \multirow{2}{*}{ Poland } & $-0.544^{\star * *}$ & -0.116 & $-2.293^{* * *}$ & $-0.383^{* *}$ & $-0.228^{\star}$ \\
\hline & $(0.149)$ & $(0.430)$ & $(0.212)$ & $(0.154)$ & $(0.127)$ \\
\hline \multirow{2}{*}{ Korea Rep } & -0.000984 & 0.367 & $-2.362^{\star \star \star}$ & 0.136 & $0.247^{*}$ \\
\hline & $(0.160)$ & $(0.442)$ & $(0.266)$ & $(0.165)$ & $(0.135)$ \\
\hline \multirow{2}{*}{ Russia } & $-0.542^{* * *}$ & -0.0869 & $-2.770^{* * *}$ & $-0.293^{*}$ & -0.203 \\
\hline & $(0.150)$ & $(0.431)$ & $(0.250)$ & $(0.159)$ & $(0.127)$ \\
\hline \multirow{2}{*}{ Turkey } & -0.0847 & 0.197 & $-2.069^{\star * \star}$ & 0.132 & $0.216^{*}$ \\
\hline & $(0.148)$ & $(0.435)$ & $(0.228)$ & $(0.159)$ & $(0.127)$ \\
\hline \multirow{2}{*}{ Ukraine } & $-0.397^{\star * *}$ & -0.0801 & $-1.456^{\star * *}$ & $-0.290^{*}$ & -0.120 \\
\hline & $(0.148)$ & $(0.433)$ & $(0.164)$ & $(0.153)$ & $(0.127)$ \\
\hline \multirow{2}{*}{ USA } & $-0.425^{\star * *}$ & 0.0657 & $-3.978^{* * *}$ & -0.179 & 0.0512 \\
\hline & $(0.157)$ & $(0.427)$ & $(0.369)$ & $(0.156)$ & $(0.127)$ \\
\hline \multirow{2}{*}{ CXP } & & $-0.0182^{\star * *}$ & & & \\
\hline & & $(0.00653)$ & & & \\
\hline \multirow{2}{*}{$\operatorname{lnGDP}$} & & & $0.532^{* * *}$ & & \\
\hline & & & $(0.0478)$ & & \\
\hline \multirow{2}{*}{ LnREER } & & & & $0.483^{* *}$ & \\
\hline & & & & $(0.232)$ & \\
\hline \multirow{2}{*}{ Dt } & & & & & $0.548^{* * *}$ \\
\hline & & & & & $(0.0485)$ \\
\hline \multirow{2}{*}{ Constant } & -0.163 & $1.132^{\star * *}$ & $-11.09^{* * *}$ & -1.071 & $0.634^{* * *}$ \\
\hline & $(0.269)$ & $(0.423)$ & $(1.104)$ & $(1.068)$ & $(0.109)$ \\
\hline Observations & 270 & 174 & 270 & 270 & 270 \\
\hline R-squared & 0.304 & 0.306 & 0.477 & 0.238 & 0.482 \\
\hline
\end{tabular}

Standard errors in parentheses $\left({ }^{* *} p<0.01,{ }^{* *} p<0.05,{ }^{*} p<0.1\right)$. 
kilograms. However, the individual countries GDPs exhibited significantly negative relationships with Malawi tobacco exports.

There was an overall positive and significant relationship between Malawi tobacco exports and real effective exchange rate over time. This implies that a unit increase ( 1 dollar) in REER, will result in an increase of Malawi tobacco exports by 0.4 kilograms. Poland, Russia and Ukraine showed significantly negative relationships between REER and Malawi tobacco exports. Only China exhibited a positive relationship between REER and Malawi tobacco exports. The rest of the countries had insignificant relationships between REER and Malawi tobacco exports.

The LSDV fixed effects model showed a positively significant relationship between Malawi tobacco export demand and WHO treaty to various destination markets over time. The introduction of the WHO treaty on tobacco supply increased Malawi tobacco export demand by 0.5 kilograms each year. On the individual countries; China, Japan, South Korea and Turkey showed a significant positive relationship with WHO treaty over time, while Poland Russia and Ukraine showed a negatively significant relationship between tobacco exports and WHO treaty.

\section{Conclusion and Policy Implications}

This paper utilized the fixed effects model on panel data to empirically estimate the export demand function for Malawi tobacco from 1997 to 2019. The results from the estimated FE model with driscoll-Kraay standard errors showed that only two out of the seven explanatory variables had statistically significant relationship with Malawi tobacco export demand, these are GDP and export price. These variables had coefficients of 0.428 and 0.0072 respectively.

The findings suggest that Malawi should take advantage of the importing countries income to enhance the country's export demand for tobacco. One way is by encouraging and supporting tobacco farmers to increase production and to produce high quality tobacco leaf. In so doing, this will increase the value of tobacco exports; the increase in the value of exports will lead to an increase in economic growth and development.

Another important finding from this study is that, on overall, the FCTC treaty did not negatively impact tobacco export demand for the country in the period examined. Therefore, Malawi should focus on investing more in the tobacco sector to increase the production while improving international trade relations in order to increase economic growth. In conclusion, Malawi needs to promote the export-led growth strategy by focusing on key agricultural products such as tobacco to the already existing international markets and also by exploring new potential markets.

\section{Limitations of the Study}

The limitations of this study include unavailability of actual values for export 
prices both for exporting country and for other competing countries. The study had to use average values which were derived from dividing the total export values by the total export quantities of raw tobacco. Another limitation was the unavailability of export data for some years for the selected importing countries.

\section{Conflicts of Interest}

The authors declare no conflict of interest regarding the publication of this paper.

\section{References}

Arize, A. C., \& Malindretos, J. (2014). Re-Examining Exchange-Rate Risk Effects and Export Trade Using the ARDL Bounds Testing Approach. International Journal of Economics and Finance, 6, 32-42. https://doi.org/10.5539/ijef.v6n7p31

Bobić, V. (2009). Income and Price Elasticities of Croatian Trade-A Panel Data Approach.

Bokosi, F. K. (2015). Export Trade and Economic Growth in Malawi: A Disaggregated Approach. International Journal of Economics and Financial Research, 1, 97-105.

FAO (2015). Malawi-Agriculture Report. 915 (September), 1-5. http://www.fao.org/3/a-i4491e.pdf

FCTC (2014). Parties to the WHO FCTC (Ratifications and Accessions). Framework Convention Alliance.

https://www.fctc.org/parties-ratifications-and-accessions-latest/\#signed

Goldstein, M., \& Khan, M. S. (1985). Income and Price Effects in Foreign Trade. II.

Gregori, T., \& Giansoldati, M. (2020). Import Demand in Heterogeneous Panel Data with Cross-Sectional Dependence. Applied Economics, 52, 443-458. https://doi.org/10.1080/00036846.2019.1645944

Guci, L. (2008). Exchange Rates and the Export Demand for U.S. Grapefruit Juice.

Hoechle, D. (2007). Robust Standard Errors for Panel Regressions with Cross-Sectional Dependence. The Stata Journal, 7, 281-312. https://doi.org/10.1177/1536867X0700700301

Ibrahim, M. A. (2012). Merchandise Export Demand Function for Egypt: A Panel Data Analysis. Applied Econometrics and International Development, 12, 107-116.

ITC (2020). Trade Map—List of Products Exported by Malawi. https://www.trademap.org/Product SelCountry TS.aspx

Jaffee, S. (2003). Malawi’s Tobacco Sector. June.

Khan, M. S. (1974). Import and Export Demand in Developing Countries (Demande à l'importation et l'exportation dans les pays en développement) (La demanda de importación y de exportación en los países en desarrollo). Staff Papers (International Monetary Fund), 21, 678-693. https://about.jstor.org/terms

Maziya, L., Tijani, A., \& Masuku, M. (2016). Estimation of Export Demand Function for Swazi Sugar: A Panel Data Analysis. International Journal of Sustainable Agricultural Research, 3, 1-18. https://doi.org/10.18488/journal.70/2016.3.1/70.1.1.18

Munemo, J., Bandyopadhyay, S., \& Basistha, A. (2007). Foreign Aid and Export Performance: A Panel Data Analysis of Developing Countries. Federal Reserve Bank of St. Louis Working Paper 2007-023. http://research.stlouisfed.org/wp/2007/2007-023.pdf 
https://doi.org/10.20955/wp.2007.023

Olofin, S., \& Babatunde, M. A. (2009). Estimating Price and Income Elasticities of SubSaharan African Exports. African Journal of Economic Policy, 16, 1-38. https://www.researchgate.net/publication/324760027 ESTIMATING_PRICE AND I NCOME ELASTICITIES OF SUB-SAHARAN AFRICAN EXPORTS

Pesaran, M. H. (2012). Testing Weak Cross-Sectional Dependence in Large Panels. 6432.

Pesaran, M. H., Shin, Y., \& Smith, R. J. (2001). Bounds Testing Approaches to the Analysis of Level Relationships. Journal of Applied Econometrics, 16, 289-326. https://doi.org/10.1002/jae.616

Saghaian, S. Y. (2017). Export Demand Estimation for U.S. Corn and Soybeans to Major.

Senhadji, A. S., \& Montenegro, C. E. (1999). Time Series Analysis of Export Demand Equations: A Cross-Country Analysis. IMF Staff Papers, 46, 259-273.

Soltani, M., \& Saghaian, S. (2012). Export Demand Function Estimation for U.S. Raisins. Export Demand Function Estimation for US Raisins Mohammad, 66, 37-39.

Sultanuzzaman, M. R., Fan, H., Mohamued, E. A., Hossain, M. I., \& Islam, M. A. (2019). Effects of Export and Technology on Economic Growth: Selected Emerging Asian Economies. Economic Research-Ekonomska Istraživanja, 32, 2515-2531. https://doi.org/10.1080/1331677X.2019.1650656

Vidal (2005). How Malawi's Livelihood Went Up in Smoke. World News, The Guardian. https://www.theguardian.com/world/2005/jun/08/hearafrica05.smoking

Zafar, A. S. (2012). Estimation of India's Export Demand Function: The Bound Test Approach. African Journal of Business Management, 6, 11266-11272. https://doi.org/10.5897/AJBM12.356

Zheng, Z., Saghaian, S., \& Reed, M. (2012). Factors Affecting the Export Demand for U.S. Pistachios. International Food and Agribusiness Management Review, 15, 139-154. 